УДК 785.071.2:305

DOI:

Свгенія Черняк, кандидат педагогічних наук, доцент кафедри інструментального виконавства та музичного мистецтва естради Мелітопольського державного педагогічного університету імені Богдана Хмельницького Світлана Міщенко, концертмейстер кафедри теорії $і$ методики музичної освіти та хореографї Мелітопольського державного педагогічного університету імені Богдана Хмельницького

\title{
СПЕЦИФІЧНІ ОСОБЛИВОСТІ ПРОЯВУ ВИКОНАВСЬКОЇ МАЙСТЕРНОСТІ КОНЦЕРТМЕЙСТЕРА-ПІАНІСТА В ПРОЦЕСІ АНСАМБЛЕВОГО МУЗИКУВАННЯ
}

У статті розглянуто специфічні особливості роботи концертмейстера-піаніста з різними інструменталістами та вокалістами. Розкрито компоненти виконавської майстерності концертмейстера в прочесі ансамблевого музикування. Визначено роль професійно важливих виконавських якостей. Особлива увага приділясться розкриттю методичних аспектів діяльності концертмейстера під час ансамблевого музикування з інструменталістами різної фахової спеціалізації, досягненню иілісній єдності між итриховими та тембровими особливостями скрипкових, духових і партією фортепіано.

Ключові слова: ансамблеве музикування; професійно важливі якості; концертмейстер; інструменталіст; виконавська майстерність.

Jim. 15.

Evgeniia Chernyak, Ph.D.(Pedagogy), Associate Professor of the Instrumental Perfomance and Variety Arts Department Melitopol Bohdan Khmelnytskiy State Pedagogical University Svitlana Mishchenko, Accompanist of the Theory and Methods of Music Education and Choreography Department Melitopol Bohdan Khmelnytskiy State Pedagogical University

\section{SPECIFIC FEATURES OF THE MANIFESTATION OF PERFORMANCE SKILLS OF THE CONCERTMASTER-PIANIST IN THE PROCESS OF ENSEMBLE PLAYING}

The article considers the prerequisites for the successful implementation of the musician in the field of concertmaster activity. Such conditions are increased concentration and activity of auditory attention at all hierarchically related stages of mastering a piece of music: from understanding the features of the part, determining the intonation, technical difficulties, auditory adaptation of parts into a single ensemble to create a holistic flexible sound ensemble.

It is established that when accompanying soloists-instrumentalists, the accompanist must have the ability to adapt the sound capabilities of the piano to the timbre-acoustic characteristics of various instruments, take into account the technical capabilities of the soloist, know the notation of scores for various instruments, flagellates, keystrokes, alto.

It is noted that the creation of a holistic instrumental ensemble with violinists is aimed at maintaining intonation purity, overcoming textural difficulties (double notes, broken chords) to control the rhythmic pulsation of instrumentalists-soloists. The art of the accompanist can be traced in the extent to which he is able to emphasize and highlight the best opportunities of the student, to remain in the shadows.

In the process of working with cellists, the accompanist must know the peculiarities of vibrato, various strokes, the use of different strings in order to achieve a special timbre.

It is determined that the specifics of the accompanist's work with wind instruments presupposes the formation of the ability to instantly transpose works in different tonalities, to adjust the timbre capabilities of soloists, to take into account the peculiarities of breathing.

Thus, the psychological competence of the accompanist is no less important than his pedagogical and performing abilities. In various situations that develop in the process of responsible concerts, competitive performances, the accompanist performs the function of a psychologist. He is able to relieve the stress of the soloist, find a bright clue to create an artistic mood and the overall atmosphere of the concert performance.

Keywords: ensemble music making; professionally important qualities; concertmaster; instrumentalist; performing skills.

$\Pi$ остановка

проблеми. Концертмейстерство являє собою як самостійний вид сформувалося у процесі практики здійснення акомпанементу в ансамблі з інструменталістами, вокалістами, оркестровими та хоровими 


\section{СПЕЦИФІЧНІ ОСОБЛИВОСТІ ПРОЯВУ ВИКОНАВСЬКОЇ МАЙСТЕРНОСТІ КОНЦЕРТМЕЙСТЕРА-ПІАНІСТА В ПРОЦЕСІ АНСАМБЛЕВОГОМУЗИКУВАННЯ}

колективами. Особистість концертмейстера приклад універсального поєднання майстерності виконавця, педагога, імпровізатора та психолога. Мистецтво концертмейстера притаманне не тільки піаністам, але й виконавцям на найрізоманітніших інструментах, тобто у всіх тих випадках, коли необхідно розв'язувати певні ансамблево-виконавські завдання [7].

Спочатку концертмейстерами називалися скрипалі, які очолювали струнну групу та відповідали за якість іiї звучання. Звісно, добра традиція збереглася до сьогодення. Конщертмейстер зустрічається і в оркестрі народних інструментів. Але історія становлення цієї важливої професії свідчить, що довгий час піаністи-концертмейстери сприймалися не рівнозначно. Суспільне визнання концертмейстера - наставника, психолога, спеціаліста $з$ інтуїтивним відчуттям соліста та непогрішним смаком починається з Італії. Саме там концертмейстер, який допомагав шліфувати майстерність вокалістам найвищого рівня, став іменуватися маестро [9].

Аналіз основних досліджень та публікацій. На сучасному етапі українського музикознавства мистецтво концертмейстера набуває статусу пріоритетної галузі виконавства та розглядається як цілісний багаторівневий феномен у різноманітті концертно-партнерської, камерно-ансамблевовиконавської, навчально-керівної та педагогічної діяльності (Каленик, 2014). Саме таке інтегроване "розуміння мистецтва піаністаконцертмейстера забезпечує його високу ефективність через осягнення історичного процесу еволюції цього фаху, суспільно-значущих художніх цінностей кожної епохи, формування відповідної системи іманентних навичок і знань та їх конструктивного використання, які керуються в процесі самовдосконалення та належного творчого рівня спільного виконання" (Молчанова, 2015). На важливість функціонального забезпечення цілісної інтерпретації творів вказує Н. Інюточкіна (2010), зауважуючи, що специфіка концертмейстерської діяльності у процесі розучування музичного матеріалу полягає в синтезі “лідера-майстра" та інструменталіста, який “супроводжує, налаштовує, підтримує”. Досягнення високого рівня виконавської майстерності стає можливим при оволодінні концертмейстером необхідними педагогічними, психологічними, сценічно-виконавськими, ансамблево-узгоджувальним компетентностями (Повзун, 2009). Л. Повзун розглядає концертмейстерство одним із напрямів “розгалуженої системи ансамблевої діяльності”. Розкриваючи зміст понять “акомпаніаторська майстерність”, “акомпаніаторське мистецтво” Т. Дорош (2015) називає їх високохудожніми видами діяльності.

Незвичайно диференціюють терміни “концертмейстер" та "акомпаніатор", хоча в методичній літературі їх часто використовують як синоніми [7]. Діяльність акомпаніатора обмежується концертними виступами. Сфера концертмейстера значно ширша. Його діяльність, крім досвіду акомпаніатора, охоплюе низку специфічних навичок у галузі різних виконавських мистецтв, потребує від нього володіння знаннями інструментальних, вокальних труднощів, вміння знайти причини виникнення виконавських недоліків та визначити правильний шлях їх своєчасного подолання. Отже, діяльність концертмейстера своєрідне поєднання педагогічних, психологічних та творчих функцій [3].

Підвищена концентрація і активність слухової уваги - дві складові успішної реалізації музиканта у сфері концертмейстерської діяльності. Важливо пам'ятати, що процес досягнення майстерності проходить кілька етапів. На першому етапі піаніст усвідомлює характерні особливості своєї партії, прагне виконувати ії бездоганно. На другому етапі концертмейстер уважно вивчає партію соліста, ретельно визначає агогіку, інтонаційну канву музичного матеріалу, технічні труднощі та ін. На третьому етапі відбувається слухова адаптація партій в єдиний ансамбль. Означений етап найважчий та відповідальний. На четвертому етапі здійснюється слухова взаємодія супроводу та сольної партії, де вони стають цілісним звуковим ансамблем. Усі вищезазначені етапи ієрархічно взаємозв'язані, тобто, порушення їх послідовності або недостатня робота на певному 3 них спричиняють невдалі виступи, відсутність виконавського ансамблю. Навпаки, досягнення гнучкого виконавського ансамблю слугує яскравим прикладом концертмейстерської майстерності піаніста [2].

Сучасний концертмейстер виступає одночасно в багатьох іпостасях. Педагог-наставник, провідний і відомий, виконавець імперативної волі соліста, чутливий друг та партнер. Вміння антиципувати - здібність за кілька тактів інтуїтивно почути будь-які фактурні, рухові зміни та миттєво зреагувати на них [3]. Бути постійним надійним партнером соліста - засвоїти мистецтво швидкої орієнтації у нотному тексті, тобто, мати навички щодо панорамного (симультанного) охоплення музичної партитури творів. Передовсім концертмейстер повинен добро володіти своїм музичним інструментом. Це не тільки певний арсенал піаністичних вмінь, але й навички вертикальної побудови, забезпечення гнучкої 


\section{СПЕЦИФІЧНІ ОСОБЛИВОСТІ ПРОЯВУ ВИКОНАВСЬКОЇ МАЙСТЕРНОСТІ КОНЦЕРТМЕЙСТЕРА-ПІАНІСТА В ПРОЦЕСІ АНСАМБЛЕВОГОМУЗИКУВАННЯ}

пульсації музичної тканини, диригентське імперативне керівництво, підкреслення характерних особливостей партії соліста та ін. Також концертмейстеру необхідно мати розвинений музичний тембральний слух, артистизм, уяву, виявляти образно-колористичні особливості змісту творів, втілювати задумки композитора в процесі створення ансамблевої інтерпретації, а також цілісний комплекс професійно важливих якостей [13].

Майбутній концертмейстер повинен швидко засвоювати музичну фактуру певного твору, миттєво охоплювати оркестрову або хорову партитуру, відрізняти головне та менш важливе в процесі розвитку матеріалу. Бажано, щоб він мав низку позитивних психологічних якостей, міг у будь-який час підбадьорити виконавця, зняти зайве напруження безпосередньо на стадії концертного виступу або перед ним.

Відповідальність концертмейстера величезна. Його слухова увага одночасно зайнята знаходженням звукового балансу в ансамблі, втіленням єдності художнього задуму, корекцією свого виконання у разі необхідності, підтримкою соліста у випадку втрати ним тексту. Коли виникають сценічні виконавські несподіванки, концертмейстерові слід пам'ятати, що виправляти помилки та зупинятися - не припустимо. Не бажано також жестикулювати, мімічно відображати на обличчі своє невдоволення. Таке напруження уваги потребує від майбутнього концертмейстера повної концентрації фізичних, духовних та енергетичних ресурсів. Отже, воля та самовладання - важливі якості, я дуже необхідні концертмейстеру. Але йому вкрай необхідно володіти навичками миттєвого транспонування, якісного читання з листа, стилістично достовірної імпровізації. Це і підбір супроводу до мелодійного абрису, і фактурна імпровізація вступу та під час завершення творів, і гнучке варіювання акомпанементу в процесі виконання однотипного музичного матеріалу. Конкретне фактурне оформлення супроводу повинно відображати такі два основні показники творів: дотримання жанрової специфіки та стильова відповідність характеру музичної тканини, особливо під час виконання характерних творів сучасних композиторів [8].

Нерідко буває, що запропонований репертуар для концертмейстера, технічно складний або піаніст не має достатнього часу щодо його шліфування. У таких випадках доцільно спрощувати фактуру, не змінюючи кардинально образний зміст та стильові особливості творів. Це стосується передовсім виконання оркестрових партитур, оперних клавірів та ін. Часто майстерні трансформації музичного матеріалу концертмейстером дають змогу виконавцям-солістам досягати кращого розуміння музичного тематизму.

Звісно, що в процесі підготовки до сценічного виступу учасники ансамблю проходять декілька стадій сумісної діяльності. Вони складаються 3 ретельного аналізу можливих виконавських інтерпретацій твору, неодноразових повторень цілого та окремих деталей, шліфування технічно важких для соліста епізодів, пошуку та варіюванню різних темпів, агогічних відхилень, всілякої координації динамічної партитури.

Ще більш складні завдання постають перед концертмейстером у роботі з хоровим колективом і вокальним ансамблем. Впевнене знання партій кожного $з$ голосів, створення достовірного слухового уявлення загального звучання вокальної партитури потребують від піаніста особливих тонкощів внутрішнього слуху, постійної взаємодії 3 цілим колективом та окремими групами хору й ансамблю. Створення виконавської інтерпретації зі солістом вокалістом пов'язане з необхідністю гнучкого проникнення у драматургічні особливості синтезу поетичного та музичного текстів. Поринути в атмосферу твору сумісно із виконавцем дуже важливо концертмейстеру, тому доцільно найчастіше працювати із талановитими співаками [2].

Основна мета якісного акомпанування досягнення загальної єдності ансамблю, яка обумовлюється гармонійним поєднанням художніх намірів партнерів виконавського процесу, одночасним розумінням ними свого функціонального значення у втіленні змістової сутності творів.

Слід також згадати про ще одну сторінку виконавського мистецтва концертмейстера. Мелодичний рух басової лінії часто залишається поза увагою свідомого сприйняття. В той же час тембральна насиченість низького регістру часто визначає характер та якісне звучання всієї фактури твору.

Майстерність концертмейстера яскраво простежується у тих моментах, коли партія роялю вирушає в сольне плавання. Вступна частина, завершення музичного твору, зв'язуючі фрагменти - в них концертмейстер нарівні із солістом бере активну участь у розвитку музичного змісту твору.

Концертний виступ - кульмінаційний підсумок копіткої праці соліста та концертмейстера, де важливо повною мірою розкрити художньообразний зміст музичного матеріалу, продемонструвати бездоганнукультуру виконання. Необхідною умовою 


\section{СПЕЦИФІЧНІ ОСОБЛИВОСТІ ПРОЯВУ ВИКОНАВСЬКОЇ МАЙСТЕРНОСТІ КОНЦЕРТМЕЙСТЕРА-ПАНІСТА В ПРОЦЕСІ АНСАМБЛЕВОГО МУЗИКУВАННЯ}

успішного виступу вважається позитивний енергетичний контакт із аудиторією слухачів. Позитивне реагування публіки сприяє здійсненню виконавського задуму ансамблістами, надихає соліста та концертмейстера на створення яскравої інтерпретації [4].

Під час виступу досвідчений концертмейстер, особливо поряд з молодими музикантами, допомагає партнерам зберегти свою індивідуальність, дотримуючись залізного правила "ніколи не бути яскравішим від соліста". Успішна діяльність концертмейстера підтримується наявністю певних якостей. Це - чуйність до партнерів, їх психологічна підтримка безпосередньо в процесі виступу та під час підготовки до нього, нівелювання випадкових помилок. А таких випадковостей може бути дуже багато. Наприклад, вокаліст втратив текстову канву, соліст запізнився зі вступом, забув свою партію, перестрибнув через кілька рядків. Концертмейстер завжди виступає у ролі музичної швидкої допомоги, коли треба нагадати слова, підіграти партію соліста, повторити або розтягнути вступ.

Ситуація концертного виступу потребує від концертмейстера максимум уваги до партнера. Почуття ансамблевої єдності виникає у тому випадку, коли концертмейстер уважно контролює кожен звук, інтонацію соліста, миттєво реагує на будь-які зміни, передбачає особливості виконання. Таким чином, мистецтво концертмейстера специфічне. Воно вимагає від музиканта різноманітності виконавських здібностей, артистизму, досконалого вивчення особливостей гри на інших музичних інструментах, знання різних співацьких голосів [2]. Так, концертмейстерська галузь музикування у класі хорового диригування передбачає не тільки засвоєння інструменталістом всього арсеналу піаністичної майстерності, але й множину додаткових вмінь. Вміння прослухати багатошарову фактуру та побудувати вертикаль, підкреслити тембральну “соковитість” голосів, забезпечити гнучку пульсацію музичної тканини, витримати вольовими зусиллями ритмічний стрижень хорового твору. Водночас мистецтво концертмейстера присвячено безкорисливому служінню солістові, ансамблю співаків, хоровому колективу.

Мета статті - визначити характерні особливості роботи концертмейстера в ансамблі зі солістами-інструменталістами.

Виклад основного матеріалу. Акомпанування солістам-інструменталістам має специфічні особливості. В цьому випадку концертмейстер повинен засвоїти навички слухання найдрібніших деталей партитури, бути спроможним адаптувати звукові можливості фортепіано до тембровоакустичних характеристик інструментів. Так, скрипкові, віолончельні, альтові акомпанементи є різними за силою звуку і тембром.

У процесі пошуку відповідної палітри супроводу духовим інструментам, слід також враховувати технічні можливості апарату соліста, звертати увагу на моменти взяття ним дихання під час виконання музичної фрази. Важливо контролювати чистоту ладу духових інструментів, ступінь їх розігріву. Доцільно при знаходженні ансамблевої єдності 3 дерев'яними та мідними інструментами коригувати силу і яскравість звучання фортепіано. Тут необхідна дуже тонка слухова орієнтація піаніста. Відомо, що рухливість струнних та дерев'яних духових інструментів значно перевищує рухливість співацького голосу. Концертмейстер також повинен знати особливості нотації партитур для різноманітних інструментів, позначки флажолетів, всіляких штрихів, альтовий та теноровий ключі. Велике значення мають індивідуально-психологічні властивості солістів, особливості гендерних проявів музикантів $[5 ; 11 ; 12]$.

Перше знайомство 3 фактурою інструментального твору слід розпочинати з виконання партії соло у супроводі спрощеного гармонійного акомпанементу. Задля цього необхідно виділити партію супроводу та звести ії гармонійну основу до ряду акордів у найпростішому вигляді. Виключаємо підголоски, зайві колористичні звуки, поліфонічні утворення та ін.

Іноді точне відтворення партії соліста не можливе, особливо при наявності там віртуозних пасажів та вокальних фіоритур. Тому рояль слугує лише додатковим засобом в процесі попереднього знайомства 3 партитурою задля отримання цілісного уявлення щодо інтонаційного змісту сольної партії. В подальшій самостійній роботі піаніст визначає принципи організації технічних фрагментів, виявляє опорні звуки та співвідносить їх 3 гармонійною основою. Таким чином, концертмейстер має нагоду добре засвоїти музичний твір, вільно орієнтуватися в усіх хитросплетіннях сольної партії [15].

Звісно, основне завдання концертмейстера сумісно з викладачем допомогти учневі засвоїти музичний твір, підготувати його до концертного виступу. Ознайомлення 3 музичною фактурою, фрагментарне виконання, цілісне програвання твору на репетиціях, сценічний виступ взаємозв'язані стадії роботи, де концертмейстер присутній від самого початку.

Часто в повсякденній роботі концертмейстер стикається 3 необхідністю акомпанувати різним 
музичним інструментам. Розглянемо особливості створення інструментального ансамблю 3 окремими із них. Збереження інтонаційної чистоти дуже важливо для скрипалів. Коли учень під час розучування програми втрачає контроль над інтонуванням (особливо це стосується високих позицій), піаністу важливо продублювати звуки мелодії. Визначений прийом доцільно також використовувати для подолання ритмічних труднощів. Має місце й тенденція до скорочення нот під час пауз у партії фортепіано. Нівелювати цю розповсюджену помилку можна при заповненні пауз функціонально близькими акордами. Взагалі часткове видозмінення фактури допомагає майбутньому скрипалю швидше засвоїти сольну партію. На першій стадії розучування твору концертмейстеру зовсім не обов'язково виконувати акомпанемент в повному обсязі. Важливо підкреслити головні басові ноти, абрис гармонії [9].

Темпоритмічний та динамічний синтез значимі складові успішного супроводу, які забезпечують цілісність виконання з певним партнером. Своєрідність темпоритму скрипаля визначається його вмінням розподіляти смичок та ступенем засвоєння ним штрихової палітри наприклад, штрих “сотійе”, котрим починають оволодівати з “Танцю” Дженкінсона. Дуже рідко учень спроможний виконувати п’єсу в стабільному темпі. Рух уповільнюється у середині, а $з$ початку репризи - повертається. Пройде певний час, коли майбутній скрипаль відчує кистьову легкість. У цьому випадку жорстка темпова пульсація, завдана концертмейстером, може призвести до зупинення виконання та завдати шкоди учневі.

Суттєвими фактурними труднощами вважається для скрипаля виконання подвійних нот, ломаних акордів. Подолання технічних фрагментів творів потребує від концертмейстера особливої агогічної гнучкості. Вміння уповільнити темп, а потім акуратно його повернути - в цьому й виражається майстерність концертмейстера.

Єдність ансамблю у процесі сумісного музикування скрипаля та піаніста залежить від вміння соліста розподіляти смичок в п'єсах кантиленного характеру. Доцільно під час виконання довгих нот прискорювати рух акомпанементу, а надалі поступово здійснювати перехід до tempo primo. Прикладом може слугувати відома п’єса К. Сен-Санса “Лебідь” 3 циклу “Карнавал тварин”.

Динамічні аспекти досягнення ансамблевої цілісності з майбутнім скрипалем пов'язані 3 технічним рівнем учня, його загальним музичним розвитком, а також специфікою окремого інструмента. Мистецтво концертмейстера простежується у тому, наскільки він спроможний підкреслити та висвітлити найкращі можливості учня, залишаючись в тіні. У цьому аспекті важливим постає питання щодо характеру фортепіанного вступу. Дуже кумедним буде виглядати в'яле звучання скрипки після яскравого віртуозного соло концертмейстера. Виразна гра піаніста не повинна перекривати емоційні можливості учня.

Ефективність сумісного музикування досягається завдяки творчому спілкуванню концертмейстера, педагога та учня. Від цього залежить не тільки музичний розвиток скрипаля, але й виховання його особистості. Відсутність агресії після зауважень викладача, зацікавленість концертмейстера успіхами учня - ця необхідна підтримка, яку відчуває майбутній інструменталіст [11].

У процесі роботи з віолончелістами велика увага приділяється шліфуванню звукової та штрихової палітри. Якісне звучання інструмента багато в чому залежить від швидкості ведення смичка, його зміни, різної атаки звуку. Концертмейстер повинен знати особливості виконання вібрато, штрихів за допомогою кінця, середини смичка, використання різних струн 3 метою досягнення особливої тембрової характерності. Все це має велике значення для розв'язання художніх завдань повноцінного ансамблевого виконання.

Нерідко при виконанні музики бароко в партії віолончелі виникають позиційні стрибки, які потребують часу. Піаніст не має права підганяти соліста, йому слід уповільнити ритмічний акомпанемент. Концертмейстеру бажано знати специфіку виконання таких штрихів, як spiccato (гра біля колодки), sautille (легке staccato y середині смичка), а також особливого staccato, котре передбачає виконання великої кількості нот на одному смичку.

Дуже важливо в процесі здійснення супроводу дослухатися до інтонаційної напруженості тембру інструмента, особливо при завершенні твору, або в інструментальних переходах від крещендо до димінуендо. Концертмейстеру слід знати, слухати та відчувати всі ці нюанси.

Нерідко виникають питання щодо виконання оркестрового вступу творів великої форми (подвійна експозиція). Скорочення музичного матеріалу доцільне, коли має місце деяка розтягнутість тканини. Ознаки вдалої купюри симетричність, природність модуляції, гармонічність. Розповсюджене в практиці 


\section{СПЕЦИФІЧНІ ОСОБЛИВОСТІПРОЯВУ ВИКОНАВСЬКОӤ МАЙСТЕРНОСТІ КОНЦЕРТМЕЙСТЕРА-ППАНІСТА В ПРОЦЕСІ АНСАМБЛЕВОГО МУЗИКУВАННЯ}

програвання кількох тактів є помилкою. Соліст не має можливості налаштуватися на входження до стильової атмосфери твору, не встигає психологічно підготуватися до виступу $[11 ; 14]$.

На сцені концертмейстер повинен підготуватися до гри раніше від партнера, коли вони починають грати одночасно. Необхідно після настройки інструмента уважно слідкувати за учнем, щоб не пропустити момент його вступу.

Наступне питання містить вирішення такої дилеми: завдати жорсткого ритму або надати можливість учню проявити самостійність. Імперативне виконання допустиме лише епізодично, у класі. Важливо створити умови щодо визначення учнем своїх намірів, показати свою гру на рівні, який він має.

Іноді віолончеліст в умовах концертного виступу не спроможний подолати технічні труднощі, тому відхиляється від темпу. Не слід підганяти його, а краще підтримати, знайти необхідний музичний консенсус. Часто концертмейстеру доводиться ловити соліста, коли він пропускає кілька тактів. Швидка реакція досвідченого майстра допомагає знівелювати помилку, звести її нанівець. Коли виникає втрата тексту, зупинка віолончеліста, концертмейстер використовує музичні підказку, грає кілька нот мелодії соліста доти, доки він на отямиться та знову почне грати. Витримка концертмейстера дає змогу уникнути виникнення в інструменталістів стресокомплексів. Для профілактики подібних ситуацій можна обговорювати з учнем певні частини форми, 3 яких зручно розпочинати свою гру.

Таким чином, ансамблеве музикування зі струнними смичковими інструментами значно збагачує слухові уявлення та темброві можливості піаніста-концертмейстера, дає можливість розвиватися у музичному плані.

Свої особливості має робота концертмейстера 3 духовими інструментами. Тут важливим навиком виступає вміння транспонувати твори в різні тональності. Особливо це стосується саксофона-альта і саксофона-сопрано, кларнета, труби. Взагалі більшість дерев'яних духових потребує транспонування акомпанементу.

У процесі виконання творів в транспорті концертмейстеру доцільно уявно відтворити п’єсу в новій тональності. При цьому іноді немає часу осмислювати кожен звук. Величезну роль відіграє вміння акомпаніатора миттєво визначати гармонійну сітку за типовою приналежністю (акорд, септакорд), мелодичний абрис, характерні функціональні зміни. Також концертмейстер повинен знати особливості здійснення дихання, артикуляції, 3 метою своєчасної компенсації затримки музичного розвитку темпом, настроєм, характером супроводу. Особливу увагу бажано приділити моментам взяття дихання, ауфтактам, точному відчуттю ритмічної пульсації. Необхідно враховувати можливості апарату солістів, уважно слухати динамічний розвиток партії виконавця, коригувати звучність фортепіано з тембральними особливостями інструментів, досягати повноцінного втілення задуму композитора [7].

Концертмейстеру важливо знати специфіку динамічної насиченості фортепіанного звучання в ансамблевій грі з різними групами духових інструментів. Звісно, що акомпанемент саксофону потребує від піаніста більшої яскравості, ніж для блокфлейти.

Що стосується мідних духових інструментів, то й тут концертмейстер стикається 3 певними специфічними особливостями. Передовсім дихання за допомогою мундштука. Функціонально корнет виступає інструментом для попередньої підготовки учнів для подальшого засвоєння труби. Концертмейстеру необхідно враховувати різкий звук інструмента, тому акомпанемент має бути виразним, чітким, яскравим. У процесі ансамблевого виконання бажано нівелювати темпову неоднорідність, змінення ритмічної пульсації та інші недоліки початківців.

Альт має невиразний тембр, тому концертмейстеру важливо знаходити необхідний баланс між партією соліста і акомпанементом. До того ж супровід доведеться транспонувати на інтервал кварти. Технічні можливості баритона близькі до можливостей тенора та інших інструментів мідної духової групи. В процесі здійснення акомпанементу, особливо творів кантиленного характеру, бажано приділяти увагу виразності фразування, цілісності форми, звуковій підтримці соліста. Труба належить до одного 3 тембрально найяскравіших інструментів серед мідних однак від природи їі звук не такий різноманітний, як, наприклад, у валторни. Приборкання різкого звуку труби - одна з найбільш важливих проблем учнів. Концертмейстеру не потрібно приглушувати звук, тому що багато творів для цього інструмента насичені інтонаціями маршу, які зумовлюються ясність, чіткість та яскравість акомпанементу.

Валторна відрізняється великим діапазоном однак вимагає постійного взяття дихання, що необхідно враховувати концертмейстеру та надавати солісту час у процесі виконання.

Тромбон - духовий мідний музичний інструмент $з$ яскравим, блискучим тембром в середньому і верхньому регістрах, й похмурим - 
у нижньому. В процесі акомпанементу концертмейстер повинен про це пам'ятати та всіляко підлаштовуватися до звучання учня.

Найнижчим за регістром інструментом вважається туба із суворим, масивним тембром. Під час виконання у соліста в неймовірних розмірах витрачається дихання що призводить до значного уповільнення темпу. В акомпанементі слід більше уваги приділяти лівій руці, підтримуючи тембр туби. Звуки в низькому регістрі на тубі звучать тьмяно, тому концертмейстерові слід прибрати звук, щоб не “перекрити" соліста.

Багато музичних творів у репертуарі учнів взагалі не мають музичного вступу. У зв'язку з цим концертмейстерові бажано надати вступну частину, яка відповідає стильовим особливостям твору.

Нерідкі випадки, коли у фортепіанній партії не вказані відтінки, наявні у соліста, тому концертмейстеру потрібно стежити за найменшими змінами в силі звучання соло інструмента.

Висновки. На сучасному етапі українського музикознавства мистецтво концертмейстера набуває статусу пріоритетної галузі виконавства та розглядається як цілісний багаторівневий феномен в різноманітті концертно-партнерської, камерно-ансамблево-виконавської, навчальнокерівної та педагогічної діяльності.

Передумовами успішної реалізації музиканта в сфері концертмейстерської діяльності виступають підвищена концентрація та активність слухової уваги на всіх ієрархічно пов'язаних етапах засвоєння музичного твору: від усвідомлення особливостей партії, визначення інтонаційної канви, технічних труднощів, слухової адаптації партій в єдиний ансамбль, до створення цілісного гнучкого звукового ансамблю.

При здійсненні акомпанементу солістамінструменталістам концертмейстеру необхідно володіти вміннями адаптувати звукові можливості фортепіано до темброво-акустичних характеристик інструментів, враховувати технічні можливості апарату соліста, знати особливості нотації партитур для різноманітних інструментів, позначки флажолетів, всіляких штрихів, альтовий і теноровий ключі.

Створення цілісного інструментального ансамблю зі скрипалями спрямоване на збереження інтонаційної чистоти, подолання фактурних труднощів (подвійні ноти, ломані акорди) контролювання ритмічної пульсації інструменталістів-солістів. Мистецтво концертмейстера простежується у тому, наскільки він спроможний підкреслити та висвітлити найкращі можливості учня, залишаючись у тіні.

У процесі роботи 3 віолончелістами концертмейстер повинен знати особливості виконання вібрато, різноманітних штрихів, використання різних струн з метою досягнення особливої тембрової характерності.

Специфіка роботи концертмейстера з духовими інструментами передбачає сформованість вміння миттєво транспонувати твори в різні тональності, коригувати тембральні можливості солістів, враховувати особливості дихання.

Отже, психологічна компетентність концертмейстера важлива не менше, ніж його педагогічні та виконавські здібності. У різних ситуаціях, які складаються в процесі відповідальних концертів, конкурсних виступів, концертмейстер виконує функцію психолога. Він здатний зняти зайву напругу соліста, знайти яскраву підказку для артистичного настрою.

\section{ЛІТЕРАТУРА}

1. Дорош Т. Л. Акомпаніаторське мистецтво в підготовці майбутнього фахівця-музиканта. Традицї та новації у вищиій архітектурнохудожній освіті, 1, 2015. 34-37.

2. Економова Е.К. Організація співтворчості : навч. посібник для концертмейстера і співака. Одеса, 2003. 208 с.

3. Инюточкина Н.В. Феномен пианистаконцертмейстера. Харьков, 2010. 67 с.

4. Йоркіна Є.Б. Специфічні особливості виконання та інтерпретації музичних творів інструменталістами різних типів. Науковий вісник HAM. Київ, 2010. № 3. С. 107-113.

5. Йоркіна Н.В., Черняк Є.Б. Особливості прояву гендерних відмінностей інструменталістів у процесі музично-виконавської діяльності. Педагогічна освіта : теорія $і$ практика. Збірник наукових праџь. Кам'янець-Подільський національний університет імені Івана Огієнка, 2018. № 24 (1-2018). С. 63 - 68.

6. Каленик I. В. Концертмейстерська діяльність - історичний та педагогічний аспекти. Молодь $i$ ринок. Щомісячний науковопедагогічний журнал. Дрогобич, 2014. № 3 (110), C. 124-128.

7. Кубанцева Е.И. Концертмейстерский класс : учебное пособие. Москва, 2002. 192 с.

8. Мітлицька В.А., Гердова Т.С., Черняк Є.Б. Фортепіанна ансамблева музика В. Птушкіна як предмет вивчення на факультетах мистецькопедагогічного спрямування. Молодь і ринок. Щомісячний науково-педагогічний журнал. Дрогобич, 2019. № 7(174). С.62 - 66. 


\section{СПЕЦИФІЧНІ ОСОБЛИВОСТІ ПРОЯВУ ВИКОНАВСЬКОЇ МАЙСТЕРНОСТІ КОНЦЕРТМЕЙСТЕРА-ПАНІСТА В ПРОЦЕСІ АНСАМБЛЕВОГОМУЗИКУВАННЯ}

9. Молчанова Т. О. Мистецтво піаністаконцертмейстера у культурно-історичному контексті: історія, теорія, практика: Монографія. Львів: Нац. муз. акад. ім. М. В. Лисенка. Львів, $2015.557 \mathrm{c}$.

10.Повзун Л. Наукові і художні аспекти мистецької діяльності піаніста-концертмейстера: автореф. ... дис. канд. мистецтвознавства за спец. 17. 00. 03. - музичне мистецтво). Київ; Інститут мистецтвознавства, фольклористики та етнології імені М. Т. Рильського НАН України. 2005. 23 с.

11. Черняк Є.Б., Йоркіна Н.В. До проблеми формування психолого-виконавської майстерності в контексті компенсаторних можливостей особистості. Матеріали міжнародної наукової конференції Мистецьька освіта: традиції $i$ новації. Мелітополь, 2014. С. 146 - 148.

12.Черняк Є.Б., Йоркіна Н.В. Формування гендерної компетентності студентів у процесі їх підготовки до умов виконавської діяльності. Вісник університету імені Альфреда Нобеля. Серія : Педагогіка і психологія, 2018. № 2(16). С. $102-109$.

13. Черняк $Є$., Карецька А. Методичні аспекти формування професійно важливих виконавських якостей учнів шкіл естетичного спрямування. Молодь і ринок. Щомісячний науковопедагогічний журнал. Дрогобич, 2019. № 5(172). C.73- 79 .

14. Черняк Є.Б. Методичні аспекти формування професійно-виконавських компетенцій музикантів 3 різними індивідуально-психологічними особливостями. Педагогічна освіта : теорія $i$ практика. Збірник наукових праць. Кам'янець - Подільський національний університет імені Івана Огієнка, 2016. № 20 (1 - 2016). С. 163 - 168.

15. Chernyak Ye., Byletskya $M$. et al. Transformation of sound cipher complexes in the history of musical art and their specific manifestations in the work of composers of the XVII-XXI centuries. Journal of History Culture and Art Research. Karabuk University, 2019. pp. $301-309$.

\section{REFERENCES}

1. Dorosh, T. L. (2015). Akompaniatorske mystetstvo $\mathrm{v}$ pidhotovtsi maibutnoho fakhivtsiamuzykanta [Associative art in the preparation of a future specialistmusician]. Traditions and innovations in higher architectural and artistic education, 1, pp. 34-37. [in Ukrainian].

2. Ekonomova, E. K. (2003). Organizaciya spivtvorchosti [Organization of co-creation]. Textbook for accompanist and singer. Odesa, 208 p. [in Ukrainian].

3. Inyutochkina, N. V. (2010). Fenomen pianista-koncertmejstera [The Pianist-Accompanist Phenomenon]. Kharkov, 67 p. [in Russian].

4. Yorkina, Ye. B. (2010). Spetsyfichni osoblyvosti vykonannia ta interpretatsii muzychnykh tvoriv instrumentalistamy riznykh typiv [Specific features of performance and interpretation of musical works by instrumentalists of different types]. Scientific Bulletin of NAM. No. 3. pp. 107-113. [in Ukrainian].

5. Yorkina, N. V. \& Chernyak, Ye. B. (2018). Osoblyvosti proiavu hendernykh vidminnostei instrumentalistiv u protsesi muzychno-vykonavskoi diialnosti [Features of manifestation of gender differences of instrumentalists in the process of musical performance]. Pedagogical Education: Theory and Practice. Collection of scientific works. Kamenetz-Podilsk National University named after Ivan Ogienko. Kamenetz-Podilsk, 24(1-2018), pp. 63-68. [in Ukrainian].

6. Kalenik, I. V. (2014). Kontsertmeisterska diialnist - istorychnyi ta pedahohichnyi aspekty. [Concert activities - historical and pedagogical aspects]. Youth and market. Monthly scientificpedagogical journal. Drogobych, Vol.3 (110), pp.124-128. [in Ukrainian].

7. Kubanceva, E.I. (2002). Koncertmejsterskij klass: uchebnoe posobie [Concertmaster class: study guide]. Moscov, 192 p. [in Russian].

8. Mitlytska, V.A., Herdova, T.S. \& Cherniak Ye.B. (2019). Fortepianna ansambleva muzyka V. Ptushkina yak predmet vyvchennia na fakultetakh mystetskopedahohichnoho [V. Ptushkin's piano ensemble music as a subject of study at faculties of art and pedagogical direction]. Youth and market. Monthly scientific-pedagogical journal. Drogobych,Vol.7 (174), pp. 62-66. [in Ukrainian].

9. Molchanova, T. O. (2015). Mystetstvo pianista-kontsertmeistera u kulturno-istorychnomu konteksti: istoriia, teoriia, praktyka: monohrafiia [The art of pianist-accompanist in the cultural-historical context: history, theory, practice: Monograph]. Lviv, 557 p. [in Ukrainian].

10. Polzun, L. (2005). Naukovi i khudozhni aspekty mystetskoi diialnosti pianista-kontsertmeistera [Scientific and artistic aspects of the artistic activity of the pianist-concertmaster]. Candidate's theasis. Kyiv; Institute of Art Studies, Folklore Studies and Ethnology named after M. T. Rylsky, National Academy of Sciences of Ukraine. [in Ukrainian].

11. Chernyak, Ye. B. \& Yorkina, N. V. (2014). Do problemy formuvannia psykholoho-vykonavskoi maisternosti $\mathrm{v}$ konteksti kompensatornykh mozhlyvostei osobystosti [The problem of the formation of psycho-performing skill in the context of the compensatory capabilities of the individual]. Materialy mizhnarodnoi naukovoi konferentsii 
Mystetska osvita: tradytsii i novatsii - Proceedings of the International Scientific Conference An art education: traditions and innovations. (pp. 146-148). Melitopol. [in Ukrainian].

12. Chernyak, Ye. B. \& Yorkina, N. V. (2016). Formuvannia hendernoi kompetentnosti studentiv $\mathrm{u}$ protsesi yikh pidhotovky do umov vykonavskoi diialnosti [Methodical aspects of the formation of professional-performing competences of musicians with different individual and psychological peculiarities]. Pedagogical Education: Theory and Practice. Collection of scientific works. KamenetzPodolsk National University named after Ivan Ogienko. Kamenetz-Podolsk, 20(1-2016). pp. 163 - 168. [in Ukrainian].

13. Cherniak, Ye. \& Karetska, A. (2019). Metodychni aspekty formuvannia profesiino vazhlyvykh vykonavskykh yakostei uchniv shkil estetychnoho spriamuvannia [Methodical aspects of formation of professionally important performing qualities of pupils of schools of aesthetic orientation.]. Youth and market. Monthly scientific-pedagogical journal. Drogobych, Vol.5(172), pp. 73-79. [in Ukrainian].

14. Chernyak, Ye. B. \& Yorkina, N. V. (2018). Metodychni aspekty formuvannia profesiinovykonavskykh kompetentsii muzykantiv z riznymy indyvidualno-psykholohichnymy osoblyvostiamy [Formation of gender competence of students in the process of their preparation to the conditions of performance]. Alfred Nobel University Bulletin. Series: Pedagogy and Psychology. Dnepr, 2(16). pp. 102 - 109. [in Ukrainian].

15. Chernyak, Ye. \& Byletskya, M. et al. (2019). Transformation of sound cipher complexes in the history of musical art and their specific manifestations in the work of composers of the XVII-XXI centuries. Journal of History Culture and Art Research. Karabuk University. pp. 301-309. [in English].

Стаття надійшла до редакції 12.02.2021

УДК 78.421;78.27

DOI:

Марія Герега, кандидат мистецтвознавства, професор, завідувач кафедри загального та спеціалізованого фортепіано Львівської національної музичної академії імені М. В. Лисенка, Заслужений діяч мистецттв Украӥни

\section{ФОРТЕПІАННІ СОНАТИ № 1 I 2 ВАСИЛЯ БЕЗКОРОВАЙНОГО З ПОЗИЩЙ ТОНАЛЬНИХ І ФОРМОТВОРЧИХ ОСОБЛИВОСТЕЙ}

У статті здійснено спробу виявити тональні та формотвірні особливості сонат Василя Безкоровайного та і їх дидактичний потенціал. Констатовано, щзо сонатні жанри в доробку композитора $\epsilon$ художньо і дидактично вартісними зразками начіонального педагогічного репертуару. На їх прикладі можливе зіставлення класичної сонатної ииклічної структури з численними індивідуально-трактованими модифікачіями і рисами фольклорних та побутових жанрів начіонального музичного мистечтва. Матеріал сонат з огляду на виконавські завдання (звукотворчі, стильові, жанрові, фактурні) иікавим є прикладом украйнського дидактичного репертуару сміливого трактування форми і тонального плану, становить добре підгрунтя для розвитку тонально-гармонічного мислення, ритмічних труднощів, пластичного мелодичного голосоведення інтервальними смугами, діалогічних перекличок далеких регістрів, різних типів акордової техніки.

Ключові слова: фортепіанне мистецтво композитори діаспори; дидактичний репертуар; формотворчі особливості; виконавські завдання.

Jim. 7.

Maria Gerega, Ph.D.(Art History), Professor, Head of the General and Specialized Piano Department Lviv Mykhaylo Lysenko National Music Academy, Honored Art Worker of Ukraine

\section{PIANO SONATAS No 1 AND 2 BY VASYL BEZKOROVAINY FROM THE POSITIONS OF TONALAND FORMATIVE FEATURES}

The article attempts to identify the tonal and formative features of Vasyl Bezkorovainy's sonatas and their didactic potential. Throughout his life, he consistently created a didactic repertoire, which was characterized by a clear understanding of pedagogical tasks and a bright national musical vocabulary, sought in each period of his work to make quality editions of these works. The sonatas were written for didactic purposes, and therefore fundamentally meet the criteria of educational compositions. They were created by an artist who had significant pedagogical experience of teaching in Ukrainian professional educational institutions of Ternopil and Zolochiv (in 